\title{
PEMERINTAHAN INDONESIA DALAM PERSFEKTIF SIYASAH SYAR'IYAH
}

\author{
Herianti \\ Program Pascasarjana \\ Universitas Islam Negeri Alauddin Makassar \\ E-mail: heriantiaf@gmail.com
}

\begin{abstract}
Abstrak
Sistem pemerintahan di Indonesia dijalankan berdasarkan konstitusi UUD 1945, dengan spirit ideologi pancasila. Mengingat Indonesia adalah Negara dengan penduduk yang sanagat majemuk, baik dari segi adat istiadat maupun agama. Sehingga dalam UUD telah dicantumkan peraturan-peraturan yang sifatnya menyeluruh dan mengikat seluruh bangsa Indonesia.

Apabila sistem pemerintahan Indonesia ditinjau dari persfektif siyasah syar'iyah (politik Islam), sedikit banyak telah sesuai dengan semangat yang Islami, walaupun secara formal tidak dijadikan sebagai landasan hukum, namun secara substansi telah tercermin dalam UUD dan Pancasila. Karena inti daripada siyasah syar'iyah adalah untuk menciptakan kesejahteraan masyarakat demi terjaganya persatuan dan kesatuan bangsa. Sebagaimana pemerintahan Indonesia dijalankan secara demokratis yang memberikan hak yang sama kepada seluruh masyarakat untuk berpartisipasi dalam roda pemerintahan dan ikut serta dalam menentukan masa depan bangsa (pemimpin).
\end{abstract}

\section{Keywords:}

Sistem Pemerintahan, Politik, Indonesia, Siyasah Syar'iyah

\section{PENDAHULUAN}

\section{A. Latar Belakang}

Indonesia adalah Negara dengan keragaman budaya dan agama, terbentang luas dari Sabang sampai Merauke, yang dihuni oleh beragam suku bangsa dengan adat kebiasaan yang sangat beragam. Konstruksi Indonesia modern juga tidak bisa dilepaskan dari keragaman itu, niai-nilai kemanusiaan yang termaktub dalam UUD 1945 serta peraturan perundangan yang berlaku merupakan hasil akomodasi dan integrasi dengan nilai-nilai lokal yang beragam tersebut. Kontribusi kebudayaan yang beragam dalam pembentukan identitas Indonesia merupakan manifestasi dari negosiasi berbagai kepentingan yang saling bersaing, khususnya antara kekuatan kebangsaan dan kekuatan Islam.

Setiap kelompok kepentingan mengusung pandangan dasar mereka mengenai struktur sosial dan sistem politik yang sesuai dengan nilai-nilai, pandangan-pandangan dan kepentingan ideologisnya, karena itulah yang dianggap sebagai sesuatu yang 
mendorong pada kemajuan bagi masa depan Indonesia. Meskipun janji akan suatu kemajuan melalui sautu ideology baru bersifat utopis, tidak berarti apa yang dirumuskan oleh masing-masing kelompok politik dipandang pesimis bagi masa depan, tetapi yang penting kesungguhan memperjuangkan dan merealisasikan nilai-nilai ideal bagi masa depan bangsa.

Persoalan politik Islam tidak bisa dilepaskan dari sejarah Islam yang multi Interpretatif. Pada satu sisi, hampir setiap orang islam percaya terhadap pentingnya prinsip -prinsip Islam dalam kehidupan politik, sementara pada sisi yang lain, karena sifat islam yang multi interpretatif tersebut, tidak ada pandangan yang monolitik mengenai bagaimana seharusnya Islam dan politik diposisikan secara tepat, yang muncul dari persoalan tersebut justru pendapat yang sangat beragam.

\section{B. Rumusan Masalah}

Adapun batasan masalah yang akan dibahas dalam tulisan ini adalah sebagai berikut:

1. Bagaimana defenisi sistem pemerintahan dan siyasah syar'iyah secara umum?

2. Bagaiamana sistem pemerintahan Indonesia dalam persfektif siyasah syar'iyah?

\section{PEMBAHASAN}

\section{A. Defenisi Sistem Pemerintahan dan Siyasah Syar'iyah}

Istilah sistem pemerintahan berasal dari gabungan dua kata sistem dan pemerintahan. Kata sistem merupakan terjemahan dari kata system (bahasa Inggris) yang berarti susunan, tatanan, jaringan, atau cara. Sedangkan Pemerintahan berasal dari kata pemerintah, dan yang berasal dari kata perintah. Dan dalam Kamus Bahasa Indonesia, kata-kata itu berarti:

1. Perintah adalah perkataan yang bermakna menyuruh melakukan sesuatau.

2. Pemerintah adalah kekuasaan yang memerintah suatu wilayah, daerah, atau, Negara.

3. Pemerintahan adalah perbuatan, cara, hal, urusan dalam memerintah. ${ }^{1}$

Maka dalam arti yang luas, pemerintahan adalah perbuatan memerintah yang dilakukan oleh badan-badan legislatif, eksekutif, dan yudikatif di suatu Negara dalam rangka mencapai tujuan penyelenggaraan negara.Dalam arti yang sempit, pemerintahan adalah perbuatan memerintah yang dilakukan oleh badan eksekutif beserta jajarannya dalam rangka mencapai tujuan penyelenggaraan negara.Sistem pemerintaha diartikan sebagai suatu tatanan utuh yang terdiri atas berbagai komponen pemerintahan yang bekerja saling bergantungan dan memengaruhi dalam mencapaian tujuan dan fungsi pemerintahan.

Sistem pemerintahan dapat didefinisikan dalam 2 kategori :

1. Definisi Sistem Pemerintahan Secara Luas

\footnotetext{
${ }^{1}$ Pusat Bahasa, Kamus Besar Bahasa Indonesia, (Jakarta: Balai Pustaka, 2002), h. 859.
} 
Secara luas sistem pemerintahan berarti menjaga kestabilan masyarakat ,menjaga tingkah laku kaum mayoritas maupun minoritas, menjaga fondasi pemerintahan, menjaga kekuatan politik, pertahanan, ekonomi, keamanan sehingga menjadi sistem pemerintahan yang kontinyu, dan demokrasi dimana seharusnya masyarakat bisa ikut turut andil dalam pembangunan sistem pemerintahan tersebut.

2. Definisi Sistem Pemerintahan Secara Sempit

Secara sempit, sistem pemerintahan hanya sebagai sarana kelompok untuk menjalankan roda pemerintahan guna menjaga kestabilan negara dalam waktu relatif lama dan mencegah adanya perilaku reaksioner maupun radikal dari rakyatnya itu sendiri.

Kata as-siyasaah merupakan kata saduran dari bahasa arab asli. Adapun maknanya, diantaranya adalah pengaturan, bimbingan, pengarahan, dan perbaikan.Sedangkan istillah as-siyasah asy-syar'iyyah (politik syar'i), termasuk istilah uniterm (terpakai dalam banyak istilah, tidak hanya pada satu istilah saja), bahkan banyak mengandung signifikasi. Oleh karena itu, lafazh "as-siyaasah" telah digunakan pada lebih dari sau makna. ${ }^{2}$

Asalnya makna siyasah (politik) tersebut diterapkan pada pengurusan dan pelatihan gembalaan.Lalu, kata tersebut digunakan dalam pengaturan urusan-urusan manusia; dan pelaku pengurusan urusan-urusan manusia tersebut dinamai politikus(siyasiyun). Dalam realitas bahasa Arab dikatakan bahwa ulil amri mengurusi (yasûsu) rakyatnya saat mengurusi urusan rakyat, mengaturnya, dan menjaganya.Dengan demikian, politik merupakan pemeliharaan (ri'ayah), perbaikan (ishlah), pelurusan (taqwim), pemberian arah petunjuk (irsyad), dan pendidikan (ta'dib). Berarti secara singkat as-siyasah asy-syar'iyyah (Politik Islam) adalah pengurusan atas segala urusan seluruh umat Islam.

Jika siyasah syar'iyah dipandang sebagai sebuah proses yang tidak pernah selesai. Maka ia senantiasa terlibat dalam pergulatan sosial dan pergumulan budaya. Nyatanya fakta seperti itu telah, sedang dan akan berjalan dalam perjalanan sejarah umat Islam. Sejalan dengan pandangan demikian, pemecahan atas pelbagai masalah yang terkait dengan ihwal siyasah syari'yah lebih bersifat kontekstual, sehingga dengan demikian gejala siyasah syari'yah menampakkan diri dalam sosok yang beragam sesuai dengan perbedaan waktu dan tempat. Meskipun demikian, nilai siyasah syar'iyah tidak serta merta menjadi nisbi (relative) karena ia memiliki kemutlakan paling tidak, ia tekait kemestian untuk selalu mewujudkan keadilan, rahmat, kemaslahatan dan hikmah. ${ }^{3}$

\section{B. Tinjauan Umum Sistem Pemerintahan Indonesia dalam Persfektif Siyasah Syar'iyah}

${ }^{2}$ Muhammad bin Shalih Al-utsaimin. Politik Islam; Ta'liq Siyasah Syar'iyah Ibu taimiyah.( Jakarta griya ilmu 2009), h.11

${ }^{3}$ Djazuli, Fiqh siyasah; Implementasi Kemaslahatan umat dalam Rambu-rambu Syariah, (Jakarta: Pranada Media, 2003), h. 1-2. 
Indonesia sebagai suatu negara yang independen memiliki suatu sistem yang digunakan untuk mengelola negaranya, sistem ini dikenal dengan sistem pemerintahan Indonesia. Dalam pertumbuhan dan perkembangan sejarah ketatanegaraan, Indonesia telah mengalami beberapa perubahan dalam sistem pemerintahan sesuai dengan situasi dan kondisi zaman.

Perkembangan sistem pemerintahan Indonesia dari tahun 1945 hingga sekarang adalah sebagai berikut:

1. Sistem Pemerintahan Periode 1945-1949

Bentuk Negara Indonesia pada periode awal adalah Kesatuan, dengan bentuk pemerintahan republic dibawah sIstem pemerintahan presidensial yang berlandaskan pada konstitusi UUD 1945.

Namun, seiring datangnya sekutu dan dicetuskannya Maklumat Wakil Presiden No.X tanggal 16 November 1945, terjadi pembagian kekuasaan dalam dua badan, yaitu kekuasaan legislatif dijalankan oleh Komite Nasional Indonesia Pusat (KNIP) dan kekuasaan-kekuasaan lainnya masih tetap dipegang oleh presiden sampai tanggal 14 November 1945. Berdasarkan Maklumat Pemerintah 14 November 1945 ini, kekuasaan eksekutif yang semula dijalankan oleh presiden beralih ke tangan menteri sebagai konsekuensi dari dibentuknya sistem pemerintahan parlementer.

\section{Sistem Pemerintahan Periode 1949-1950}

Adanya Konferensi Meja Bundar (KMB) antara Indonesia dengan delegasi Belanda menghasilkan keputusan pokok bahwa kerajaan Balanda mengakui kedaulatan Indonesia sepenuhnya tanpa syarat dan tidak dapat dicabut kembali kepada RIS selambat-lambatnya pada tanggal 30 Desember 1949. Dengan diteteapkannya konstitusi RIS, sistem pemerintahan yang digunakan adalah parlementer. Namun karena tidak seluruhnya diterapkan maka Sistem Pemerintahan saat itu disebut Parlementer semu.

\section{Sistem Pemerintahan Periode 1950-1959}

Bentuk Negara Indonesia pada periode ini adalah kesatuan dengan bentuk pemerintahan republic dibawah system pemerintahan parlementer yang berlandaskan pada konstitusi UUDS 1950.

UUDS 1950 adalah konstitusi yang berlaku di negara Republik Indonesia sejak 17 Agustus 1950 hingga dikeluarkannya Dekrit Presiden 5 Juli 1959. Pemilihan Umum 1955 berhasil memilih Konstituante secara demokratis, namun Konstituante gagal membentuk konstitusi baru hingga berlarut-larut. Pada 5 Juli 1959 pukul 17.00, Presiden Soekarno mengeluarkan dekrit yang diumumkan dalam upacara resmi di Istana Merdeka.Isi dekrit presiden 5 Juli 1959 antara lain : Kembali berlakunya UUD 1945 dan tidak berlakunya lagi UUDS 1950.

Dekrit 5 juli 1959 menjadi tonggak baru politik Indonesia. Soekarno menempati posisi sangat dominan dan menjadi pusat kekuasaan. Lembaga yang 
dibentuk atas dasar keinginan Soekarno dan sekaligus merehabilitasi kekuasaannya yang selama lebih dari satu decade tidak dinikmatinya. ${ }^{4}$

\section{Sistem Pemerintahan Periode 1959-1965}

Pada periode ini Indonesia menganut sistem demokrasi terpimpin. Pandangan A. Syafi'i Ma'arif, demokrasi terpimpin sebenarnya ingin menempatkan Soekarno sebagai "Ayah" dalam famili besar yang bernama Indonesia dengan kekuasaan terpusat berada di tangannya. Dengan demikian, kekeliruan yang besar dalam Demokrasi Terpimpin Soekarno adalah adanya pengingkaran terhadap nilai-nilai demokrasi yaitu absolutisme dan terpusatnya kekuasaan hanya pada diri pemimpin. Selain itu, tidak ada ruang kontrol sosial dan check and balance dari legislatif terhadap eksekutif.

Kekuatan politik pada masa ini terbagi dalam dua kelompok besar yakni kelompok yang mendukung demokrasi terpimpin yang diwakili oleh PNI, NU, Parkindo, Partai Katolik dan PKI, sementara yang menentang adalah Masyumi dan PSI. Tidak hanya kalangan Islam (Masyumi) yang menetang demokrasi terpimpin, tetapi juga para intelektual terkemuka seperti Moh.Hatta seorang tokoh yang memiliki komitmen tegas dan konsisten kepada demokrasi menyebutkan bahwa tindakan Soekarno itu bertentangan dengan Pancasila, Karena jelas-jelas merobek prinsip-prinsip demokrasi yang begitu kokoh tercantum dalam UUD.Bahkan tidak sejalan dengan prinsip gotong royong yang didengungkan Soekarno. ${ }^{5}$

\section{Sistem Pemerintahan Masa Orde Baru (1968-1998)}

Pada Tahun 1968 MPR resmi melantik Soeharto sebagai Presiden kedua Negara Indonesia dengan masa jabatan 5 tahun dimana Soeharto menggantikan posisi Presiden Soekarno.Pada prakteknya Presiden Soeharto dipilih berturut-turut dari tahun 1973, 1978, 1983, 1988, 1993, 1998. Pemilihan Presiden pada masa itu tampak sekali tidak demokratis karena yang terpilih ulang adalah Presiden Soeharto dan Presiden Soeharto berhasil menduduki jabatan sebagai Presiden Indonesia selama 32 tahun.

Dalam bidang politik Presiden Soeharto mengawali masa jabatannya dengan mendaftarkan lagi Indonesia sebagai anggota PBB pada tanggal 28 September tahun 1966.

Pada tahun 1997 Indonesia dilanda krisis moneter yang merupakan dampak dari Krisis Finansial Asia sehingga perekonomian Indonesia hancur salah satu akibatnya adalah kurs rupiah terjun bebas dari Rp 2.500 sampai Rp 20.000 sehingga terjadi inflasi menyebabkan investor-investor asing menarik semua sahamnya dan tidak mempercayai Indonesia sebagai Negara tempat mereka menanamkan sahamnya. Situasi yang sulit yang melanda bangsa Indonesia mempengaruhi semua bidang dan berakhirlah masa pemerintahan Presiden Soeharto ditandai dengan demo besar-besaran yang dilakukan

\footnotetext{
${ }^{4}$ Syraifuddin Jurdi, Kekuatan Politik Indonesia (Makassar: Alauddin University Press, 2012), h. 122.

${ }^{5}$ Syarifuddin Jurdi, Kekuatan Politik Indonesia, h. 124.
} 
oleh mahasiswa (tragedi trisakti). Melihat masyarakat yang memberontak maka presiden Soeharto mengajukan pemunduran diri sebagai presiden Indonesia pada 21 Mei tahun 1998. Dari kategori kepemimpinan sohaerto diatas dapat kita analisa lagi bagaimana sistem pemerintahan Orba. Masa Orde Baru merupakan masa yang terkenal dengan Pembangunan Nasional yang begitu pesat. Masa Orde Baru terfokus dengan penerapan Pancasila dalam segala bidang.

\section{Sistem Pemerintahan Masa Reformasi}

Masa Reformasi ditandai dengan lengsernya Presiden Soeharto pada tanggal 21 Mei 1998 dari kursi kepresidenan. Jabatan presiden kemudian diisi oleh wakil presiden, Prof. DR. Ir. Ing. B.J. Habibie. Turunnya presiden Soeharto disebabkan karena tidak adanya lagi kepercayaan dari rakyat terhadap pemerintahan Orde Baru. Bergulirnya Reformasi yang mengiringi keruntuhan rezim tersebut menandakan tahap awal bagi transisi demokrasi Indonesia.

Transisi demokrasi merupakan fase krusial yang kritis karena dalam fase ini akan ditentukan ke mana arah demokrasi akan dibangun. Masa Reformasi merupakan masa transisi, dapat kita lihat penerapan Sistem Pemerintahan Presidensial pada masa itu mulai bangkit dengan tumbuhnya proses demokrasi. Asas Sentralisasi berubah menjadi asas Desentralisasi, dimana penyerahan kekuasaan dari pusat ke daerah. Dengan adanya penyerahan kekuasaan dari pusat ke daerah hal ini membawa dampak positif yaitu pembangunan di daerah akan lebih terfokus.

Pemerintahan Prof. DR. Ir. Ing.B.J Habibie tidak berlangsung lama dimulai tanggal 21 Mei 1998 dan berakhir pada tanggal 20 Oktober 1999. Beliau hanya menjalankan kepemimpinan transisi dan tidak mau dipilih lagi pada pemilihan Presiden berikutnya. Perubahan yang dilakukan Presiden B.J Habibie adalah membangun pemerintahan yang transparan dan dialogis. Beliau membebaskan para tahanan politik dan mengurangi kontrol kebebasan berpendapat dan kegiatan organisasi. Gaya kepemimpinan Presiden B.J Habibie adalah ramah dan supel di kalangan media massa.

Prof. DR. Ir. Ing B.J Habibie kemudian digantikan oleh Kyai Haji Abdurrahman Wahid yang lebih terkenal dengan nama Gus Dur. Pada Masa pemerintahan Gus Dur sistem politik lebih demokratis, lebih menghargai HAM, menghargai perbedaan agama, suku, ras dan adat. Masa pemerintahan Presiden Abdurrahman Wahid berlangsung dari tahun 1999 sampai dengan 2001 dan digantikan dengan wakil presidennya yaitu Megawati Soekarno Putri. Pada tahun 2004 diadakan pemilu secara langsung dan yang memperoleh suara terbanyak adalah Susilo Bambang Yudhoyono sehingga Susilo Bambang Yudhoyono resmi dilantik sebagai presiden Republik Indonesia keenam menggantikan Megawati Soekarno Putri. Pada tahun 2009 diadakan pemilu dan presiden Susilo Bambang Yudhoyono dipercaya masyarakat untuk menjabat sebagai presiden ketujuh bangsa Indonesia untuk periode 2009-2014.

Pada masa Reformasi dalam bidang politik mulai banyak terjadi pembenahan strukrutur pemerintahan (reformasi birokrasi), mulai banyak bermunculan partai politik 
baru dan PNS (abdi negara) dilarang untuk ikut berpolitik. Dalam Bidang Ekonomi terjadi banyak pembenahan dan sekarang Indonesia sedang bersaing dengan ekonomi global. Dalam pemerintahan Presiden Susilo Bambang Yudhoyono memberikan alternative bagi masyarakat yang kurang mampu dengan program BLT (Bantuan Langsung Tunai) agar mempermudah masyararakat yang kurang mampu dalam membiayai kehidupan ekonomi.

Dalam kenyataannya sebagian dari syariat Islam khususnya yang menyangkut hukum kekeluargaan telah berjalan di Indonesia selama berabad-abad, sekalipun belum ada kodifikasi hingga masa kolonialisme. Ketika Belanda dalam hal ini VOC menjajah Indonesia, pengadilan terpisah bagi golongan Eropa dan pribumi diperkenalkan. Untuk golongan pribumi, hukum adat diterapkan, dengan pembagian wilayah Indonesia ke dalam beberapa yuridiksi berdasarkan kriteria kultural dan linguistic di berbagai wilayah ini diidentifikasi dan diklasifikasi 19 sistem hukum adat yang berbeda.

Pada ranah politik, isu penerapan syariat Islam telah menjadi agenda perdebatan sejak menjelang kemerdekaan Indonesia. Perdebatan serius dalam BPUPKI pada pertengahan 1945 tentang dasar dan filsafat Negara berjalan alot. Gagasan Negara berdasarkan Islam, dengan implikasi pemberlakuan syariat Islam, yang diperjuangkan sebagian anggota BPUPKI, dan Negara sekuler yang diperjuangkan anggota lain , akhirnya mencapai kompromi dalam bentuk piagam Jakarta (22 Juni 1945) dirumuskan sebuah panitia kecil yang diketuai Sukarno.

Piagam Jakarta sebenarnya merupakan mukaddimah bagi konstitusi yang diajukan dalam sidang BPUPKI. Didalamnya pancasila sebagai dasar Negara diakui, dengan tambahan tujuh kata dalam butir pertamanya, yakni; (ketuhanan) dengan kewajiban menjalankan syariat Islam bagi pemeluk-pemeluknya. Namun dalam pertemuan mendadak pada 18 Agustus 1945, ketujuh kata tersebut disepakati penghapusannya dalam pancasila dan UUD 1945. Dalam pancasila sila Ketuhanan mendapat atribut tambahan "Yang Maha Esa" untuk mengakomodasi tuntutan wakilwakil umat Islam. Dengan kompromi terakhir ini, perjuangan menjadikan Indonesia sebagai Negara Islam yang memberlakukan syariat menjadi tidak mungkin karena bertentangan dengan UUD 1945 yang telah disepakati. ${ }^{6}$

Pada masa Indonesia modern, hubungan Islam dan kekuasaan mengalami perkembangan yang menarik. Pada era awal kemerdekaan, umat Islam dengan leluasa memperoleh kesempatan untuk mengaktualisasikan gagasan-gagasan politik Islam yang mereka usung, namun kandas terbentur oleh kondisi sosio politik ketika itu. Pada eraera berikutnya Islam dianggap sebagai kekuatan yang dicurigai.Ada ketakutan dari penguasa, bahwa kalau mereka memberikan kesempatan kepada politik Islam untuk

${ }^{6}$ Taufik Adnan Amal dan Samsu Risal Panggabean, Politik Syariat Islam; Dari Indonesia hingga Nigeria (Jakarta: Pustaka Alvabet, 2004), h. 61. 
berkembang maka berpotensi untuk membahayakan banguan bangsa Indonesia yang majemuk. $^{7}$

Di Indonesia sekalipun Islam tidak merupakan dominasi pemenangan agama secara formal tetapi ia merupakan salah satu sumber hukum bagi pembentukan hukum nasional. Pada kurun waktu terakhir, secara material dan formal pelaksanaan hukum perdata bagi umat Islam sudah diatur berdasarkan hukum Islam, yang diturunkan dari syari'at hukum Islam.

\section{PENUTUP}

\section{A. Kesimpulan}

Sistem pemerintahan di Indonesia dijalankan berdasarkan konstitusi UUD 1945, dengan spirit ideologi pancasila. Mengingat Indonesia adalah Negara dengan penduduk yang sanagat majemuk, baik dari segi adat istiadat maupun agama. Sehingga dalam UUD telah dicantumkan peraturan-peraturan yang sifatnya menyeluruh dan mengikat seluruh bangsa Indonesia.

Apabila sistem pemerintahan Indonesia ditinjau dari persfektif siyasah syar'iyah (politik Islam), sedikit banyak telah sesuai dengan semangat yang Islami, walaupun secara formal tidak dijadikan sebagai landasan hukum, namun secara substansi telah tercermin dalam UUD dan Pancasila. Karena inti daripada siyasah syar'iyah adalah untuk menciptakan kesejahteraan masyarakat demi terjaganya persatuan dan kesatuan bangsa. Sebagaimana pemerintahan Indonesia dijalankan secara demokratis yang memberikan hak yang sama kepada seluruh masyarakat untuk berpartisipasi dalam roda pemerintahan dan ikut serta dalam menentukan masa depan bangsa (pemimpin).

\section{DAFTAR PUSTAKA}

Pusat Bahasa. Kamus Besar Bahasa Indonesia. Jakarta: Balai Pustaka, 2002.

Al-utsaimin, Muhammad bin Shalih. Politik Islam; Ta'liq Siyasah Syar'iyah Ibu taimiyah. Jakarta griya ilmu, 2009.

Djazuli.Fiqh siyasah; Implementasi Kemaslahatan umat dalam Rambu-rambu Syariah.Jakarta: Pranada Media, 2003.

Jurdi, Syraifuddin Jurdi.Kekuatan Politik Indonesia. Makassar: Alauddin University Press, 2012.

\footnotetext{
${ }^{7}$ Muhammad Iqbal dan Amin Husein Nasution, Pemikiran Politik Islam; Dari Masa Klasik Hingga Indonesia Kontemporer, (Jakarta: Kencana Pranada Group, 2010), h. 308.
} 
Herianti

Panggabean, Taufik Adnan Amal dan Samsu Risal. Politik Syariat Islam; Dari Indonesia hingga Nigeria. Jakarta: Pustaka Alvabet, 2004.

Nasution, Muhammad Iqbal dan Amin Husein. Pemikiran Politik Islam; Dari Masa Klasik Hingga Indonesia Kontemporer. Jakarta: Kencana Pranada Group, 2010. 